\title{
Assessment of the prescription of red blood cell concentrates in the pediatric age group
}

\author{
João Carlos Pina Faria ${ }^{1 *} \odot$, Camila Augusta Victorino ${ }^{2}$, Fabíola Isabel Suano de Souza ${ }^{3}$, Roseli Oselka Saccardo Sarni ${ }^{4}$ \\ ${ }^{1} \mathrm{MD}$, Pediatrician and Hematology Preceptor, Faculdade de Medicina do ABC (FMABC), Santo André, SP, Brazil \\ ${ }^{2} \mathrm{MD}$, Hospital São Bernardo, São Bernardo do Campo, SP, Brazil \\ ${ }^{3}$ Assistant Professor, Department of Pediatrics, FMABC, and Adjunct Professor, Department of Pediatrics, Escola Paulista de Medicina - Universidade Federal de São Paulo (EPM-Unifesp), São Paulo, SP, Brazil \\ ${ }^{4}$ Full Professor, Department of Pediatrics, FMABC, Santo André, SP, Brazil
}

Study conducted at the Department of Pediatrics, Faculdade de Medicina do ABC (FMABC), Santo André, SP, Brazil

Article received: $7 / 4 / 2017$ Accepted for publication: 8/23/2017

*Correspondence:

Departamento de Pediatria, Faculdade de Medicina do ABC Address: Av. Lauro Gomes, 2.000 Vila Sacadura Cabral

Santo André, SP - Brasil Postal code: 09060-870 jocapf79@gmail.com

\section{SUMmARY}

Objective: To verify the adequacy of red blood cell (RBC) prescription to pediatric patients in different sectors of a pediatric hospital.

Method: A retrospective study was conducted including 837/990 RBC transfusion requisition forms for children and adolescents ( 0 to 13 years old) filed in between January 2007 and April 2015 by the pediatricians of the emergency room (ER), infirmary ward and intensive care unit (pICU). Transfusion requisition forms belonging to patients with chronic anemia or acute hemorrhage, as well as incompletes requisition forms, were excluded.

Results: Trigger, prescribed volume and subtype of RBC concentrates were adequate in $532(65.3 \%), 460$ (58.8\%) and 805 (96.2\%) of the transfusions, respectively. When the clinical picture was considered, prescription adequacy was higher compared to the use of the hemoglobin level alone (70.9\% vs. $41 \%)$. The pICU had the highest correct trigger percentage (343 [71.6\%]; $\mathrm{p}<0.001)$ while the ER showed more often adequate prescribed volumes (119 [66.1\%]; $\mathrm{p}=0.020)$. The most common inadequacy regarding volume was that of prescriptions above the recommendation $>15 \mathrm{~mL} / \mathrm{kg}$ found in 309 cases (36.9\%). Thirty-two (32) RBC subtypes were requested and none were consistent with current recommendations.

Conclusion: The results obtained in our study showed that RBC transfusion occurred more appropriately when the clinical picture was taken into account at request. There was a tendency to prescribe higher volumes and RBC subtypes without the justification of current protocols. Hemotherapic teachings at undergraduate level and medical residency must be improved.

Keywords: Transfusion Medicine. Erythrocyte Transfusion. Child. Prescriptions.

\section{INTRODUCTION}

Performed since the $17^{\text {th }}$ century, blood transfusion entered its scientific era in 1901 with the discovery of the ABO blood system by Karl Landsteiner. ${ }^{1}$ Initially, the goal of transfusions was to maintain a hemoglobin $(\mathrm{Hb})$ level greater than or equal to $10 \mathrm{~g} / \mathrm{dL} .{ }^{2}$ Later, especially in the last two decades, publications have shown safety and superior results with lower triggers. Normovolemic patients were shown to tolerate $\mathrm{Hb}$ concentrations between 5 and $6 \mathrm{~g} / \mathrm{dL} .{ }^{3}$ Regardless of the cause of anemia (decreased production of red blood cells, hemolysis or bleeding), ${ }^{4}$ the goal of transfusion is to normalize the transport of oxygen ${ }^{2}$ and, therefore, the transfusion trigger has different values in different situations, ranging from $\mathrm{Hb}$ $7 \mathrm{~g} / \mathrm{dL}$ in clinically stable children, ${ }^{5-8}$ with acute bleeding ${ }^{9}$ and sepsis but no shock; ${ }^{10}$ to $7-8 \mathrm{~g} / \mathrm{dL}$ in the postsurgical period, ${ }^{11-14}$ and $10 \mathrm{~g} / \mathrm{dL}$ in case of severe sepsis or septic shock. ${ }^{15,16}$

Despite this knowledge, several services still adopt different transfusion protocols even for patients in similar clinical contexts, so that higher triggers relate to a greater frequency of transfusion reactions. ${ }^{3,7,8,17,18}$

Transfusion is a mortality risk factor in critically ill children ${ }^{19}$ and may cause immune and non immune-mediated reactions including, more frequently: febrile nonhemolytic transfusion reaction, hemolytic reaction, alergies, 
volume overload and infections. ${ }^{1,2,5,20}$ Microcirculatory changes can also occur, ${ }^{5,21}$ as well as increased incidence of cancers. ${ }^{22}$ Reactions may occur in $0.95 \%{ }^{23}$ to $3.8 \%$ of cases..$^{24}$

Calculation of the correct volume is also important, since low volume results in less than ideal yield and high volume is associated with risk of circulatory overload. This is one of the most common transfusion reactions, with a mortality rate of $12 \%{ }^{20} \mathrm{In}$ children with acute anemia and normovolemia, a volume of transfused red blood cells (RBC) concentrates between $10^{25-27}$ and $15^{25} \mathrm{~mL} / \mathrm{kg}$ is indicated.

An appropriate choice of RBC subtype (filtered, irradiated, washed and phenotyped) influences the transfusion yield and causes fewer transfusion reactions in specific contexts. ${ }^{2,25}$ Filtered RBC has $99 \%$ of its neutrophils removed and is indicated mainly to avoid febrile nonhemolytic reaction in polytransfusion and the transmission of cytomegalovirus in immunosuppressed patients. ${ }^{25}$ $\mathrm{RBC}$ concentrates irradiated at 25 gray prevents clonal proliferation of donor lymphocytes in the immunodepressed recipient, thereby avoiding transfusional graft versus host disease. ${ }^{25}$ Washed RBCs have the highest possible amount of their plasma replaced with $0.9 \%$ saline solution in order to remove plasma proteins that may cause anaphylactic reaction in individuals with congenital deficiency of some serum protein (immunoglobulin A, haptoglobin and ferritin) or who already presented a severe allergic reaction to the previous transfusion. ${ }^{25} \mathrm{Phe}-$ notyped RBC is transfused to patients that required extended compatibility research between donor and recipient, in addition to ABO and Rh blood groups (kell, Duffy, Kidd and MNS). In pediatrics, this phenotyping procedure is carried out mainly in the poly-transfused to avoid erythrocyte alloimmunization. ${ }^{25}$

There are few studies evaluating the adequacy of RBC prescription in pediatrics ${ }^{7,9,14}$, and those available in the literature evaluated the trigger, but not the volume and subtype indicated.

The objective of our study was to evaluate the transfusional trigger, the prescribed volume and the choice of red blood cell subtypes in children admitted into a public hospital and compare with current recommendations in the literature.

\section{Method}

A retrospective study carried out at Hospital e Pronto-Socorro Central de São Bernardo do Campo, in the Greater São Paulo area, Brazil. We reviewed the transfusion requisition forms for children and adolescents from 0 to 13 years of age, filled out by pediatricians from three sectors: Emergency room (ER), the infirmary ward and the pediatric intensive care unit (pICU) from January 2007 to April 2015.

During the study period, the pediatrics consisted of four beds in the emergency room, five in the observation room, 40 in the infirmary ward, and five pICU beds. The hospital did not include an obstetrical center, a nursery, a surgical center or oncology/hematology service. It did have a transfusion agency that stored some blood components and performed simple tests such as $\mathrm{ABO}$ and $\mathrm{Rh}$ blood typing, and direct and reverse cross-tests. Whenever a subtype of blood component was requested and the transfusion agency did not have it, the request was sent to the head office in the city of São Paulo. The supplied RBC preservative solution was CPDA-1 (citrate, phosphate, dextrose and adenine).

Of the 990 RBC transfusions performed during the study period, 837 were included in the series. In all, 94 and 59 transfusion requests were excluded because they were made for patients with chronic anemia (81-sickle cell disease, 11-bone marrow aplasia, 1-hemoglobinopathy $\mathrm{C}$ and 1-spherocytosis) and acute hemorrhage, respectively, on account of trigger variability in these two conditions and the absence of information in the form, which are essential for assessing adequacy. Later, we excluded 23 other requests from the transfusion trigger analysis and 55 from the prescribed volume analysis, as $\mathrm{Hb}$ value and the patient's weight, respectively, were not recorded.

In order to assess the adequacy of the transfusional trigger, prescribed volume and choice of RBC subtypes, we used the 2015 recommendations of the Brazilian Ministry of Health..$^{25}$ However, these guidelines do not discuss some of the situations found in our study. Therefore, to analyze the transfusion trigger in children older than 4 months, with acute normovolemic anemia but otherwise stable, we used the 2012 recommendations of the American Association of Blood Banks $(7 \mathrm{~g} / \mathrm{dL}) .{ }^{6}$ To analyze the trigger in cases of septic shock, we used the recommendations of the American Heart Association - Pediatric Advanced Life Support $(10 \mathrm{~g} / \mathrm{dL}){ }^{27}$

Data collected from the transfusion requisition forms:

- General: age (months), gender, presence of underlying conditions and origin of the transfusion request form (ER, infirmary ward or pICU).

- Transfusion characteristics:

- Trigger (reason and justification for transfusion): evaluated whether it was based solely on $\mathrm{Hb}$ value or clinical-laboratory correlation. All transfusions performed in patients with $\mathrm{Hb}$ levels below $7 \mathrm{~g} / \mathrm{dL}$ were considered adequate. Requests for patients with $\mathrm{Hb}$ greater than or equal 
to $7 \mathrm{~g} / \mathrm{dL}$ were evaluated individually, taking into account the clinical reason, the presence of underlying disease and if there was hemodynamic decompensation.

- Volume prescribed: Volumes between 10 and $15 \mathrm{~mL} / \mathrm{kg}$ were considered adequate.

- RBC subtype: the request for filtered, irradiated, washed or phenotyped components was evaluated, considering the presence of underlying disease and the patient's history.

The study was approved by the Research Ethics Committee of Faculdade de Medicina do ABC (Opinion no. 1.402.884).

The data were typed and consolidated into an Excel (Microsoft) worksheet and analyzed using SPSS 24.0 statistical program. Qualitative variables were described in the form of absolute numbers and percentages. Continuous variables were analyzed for their distribution and presented as mean \pm standard deviation. To compare the qualitative data we used the Chi-square test. The confidence level was $5 \%$.

\section{Results}

In our sample, the male gender predominated (471 [56.3\%]), the mean age was $23.3 \pm 8$ months and the median was 8 months; 504 (60.2\%) of the transfusions were performed in children less than 12 months old and the most common clinical contexts were hemodynamic and respiratory changes (Table 1). Regarding the origin of the transfusion request, 201 (24\%) were made in the ER, 148 (17.7\%) in the infirmary ward and 488 (58.3\%) in the pICU (Table 1). A greater percentage of transfusions in patients older than 12 months were performed in the pICU compared to the ER and the infirmary ward (329 [65.2\%] vs. 75 [14.9\%] vs. 100 [19.8\%], $\mathrm{p}<0.001)$. There was no difference between the places of origin of the transfusion request in relation to gender $(p=0.441)$ and presence of underlying diseases $(\mathrm{p}=0.061)$.

The most common inadequacy, in relation to volume, was prescription above the recommendation $(>15 \mathrm{~mL} / \mathrm{kg}$; 309 [36.9\%]) (Table 1). Mean $\mathrm{Hb}$ and mean prescribed volume were $8.3 \pm 1.5 \mathrm{~g} / \mathrm{dL}$ (range: 2.6 to $16.1 \mathrm{~g} / \mathrm{dL}$ ) and $15.2 \pm 4.3 \mathrm{~mL} / \mathrm{kg}$ (range: 4.9 to $57.1 \mathrm{~mL} / \mathrm{kg}$ ), respectively.

The clinical status was considered in $682(81.5 \%)$ of transfusions (Table 1). There were 663 transfusions with a description of the clinical context that caused it (Table 1).

Trigger, prescribed volume and subtype of red cell concentrate were adequate in 532 (65.3\%); 460 (58.8\%) and 805 (96.2\%) of transfusions, respectively (Table 2).
TABLE 1 General characteristics for the

transfusions performed.

\begin{tabular}{|c|c|c|c|}
\hline \multicolumn{2}{|l|}{ Variable } & \multirow{2}{*}{$\begin{array}{l}\mathbf{N} \\
471\end{array}$} & \multirow{2}{*}{$\begin{array}{l}\% \\
56.3\end{array}$} \\
\hline Gender & Male & & \\
\hline & Female & 366 & 43.7 \\
\hline \multirow[t]{5}{*}{ Age } & $<1$ year & 504 & 60.2 \\
\hline & 1 to 2 years & 123 & 14.7 \\
\hline & 2 to 5 years & 108 & 12.9 \\
\hline & 5 to 10 years & 74 & 8.8 \\
\hline & $>10$ years & 28 & 3.3 \\
\hline \multirow[t]{7}{*}{ Clinical status } & Septic shock & 287 & 34.3 \\
\hline & Acute respiratory failure & 124 & 14.8 \\
\hline & Pneumonia & 117 & 14 \\
\hline & Hemodynamic decompensation & 55 & 6.6 \\
\hline & Mechanical ventilation & 32 & 3.8 \\
\hline & Other & 48 & 5.7 \\
\hline & Not described & 174 & 20.8 \\
\hline \multirow[t]{5}{*}{ Underlying disease } & Congenital heart disease & 38 & 4.5 \\
\hline & NPCE & 18 & 2.2 \\
\hline & Nephrotic syndrome & 10 & 1.2 \\
\hline & Other & 29 & 3.5 \\
\hline & No underlying disease & 742 & 88.6 \\
\hline \multirow[t]{3}{*}{ Origin } & ER & 201 & 24.0 \\
\hline & Infirmary & 148 & 17.7 \\
\hline & plCU & 488 & 58.3 \\
\hline \multirow[t]{3}{*}{ Reason } & Clinical & 14 & 1.7 \\
\hline & Laboratorial & 155 & 18.5 \\
\hline & Both & 668 & 79.8 \\
\hline \multirow[t]{4}{*}{ Pre-transfusion $\mathrm{Hb}$} & $<7 \mathrm{~g} / \mathrm{dL}$ & 125 & 14.9 \\
\hline & 7 to $10 \mathrm{~g} / \mathrm{dL}$ & 582 & 69.5 \\
\hline & $>10 \mathrm{~g} / \mathrm{dL}$ & 107 & 12.8 \\
\hline & Lack of $\mathrm{Hb}$ record & 23 & 2.7 \\
\hline \multirow[t]{4}{*}{ Volume } & $<10 \mathrm{~mL} / \mathrm{kg} /$ day & 13 & 1.5 \\
\hline & 10 to $15 \mathrm{~mL} / \mathrm{kg} /$ day & 460 & 55 \\
\hline & $>15 \mathrm{~mL} / \mathrm{kg} /$ day & 309 & 36.9 \\
\hline & Lack of weight record & 55 & 6.6 \\
\hline \multirow[t]{6}{*}{ Subtype } & Plain RBC & 805 & 96.2 \\
\hline & RBC with subtype $(s)^{*}$ & 32 & 3.8 \\
\hline & Filtered & 24 & 2.9 \\
\hline & Irradiated & 17 & 2.0 \\
\hline & Washed & 10 & 1.2 \\
\hline & Phenotyped & 0 & 0 \\
\hline
\end{tabular}

*In some RBC concentrates there was a request for more than one subtype, so the sum of filtered, irradiated and washed is greater than the number of RBC packs with subtypes. ER: emergency room; NPCE: non-progressive chronic encephalopathy; $\mathrm{Hb}$ : hemoglobin; pICU: pediatric intensive care unit; RBC: red blood cells.

Among the clinical contexts that led to the indication of transfusion, there was a high adequacy in critically-ill children (94.5\%, hemodynamic decompensation; $92.7 \%$, acute respiratory failure; $87.5 \%$, mechanical ventilation; 
$83.6 \%$, septic shock). However, the adequacy was lower in children with non-severe conditions at the time of transfusion, such as pneumonia without respiratory failure or mechanical ventilation, with only $12 \%$ (Table 2 ).

pICU had the highest correct trigger percentage ( 343 [71.6\%]; $\mathrm{p}<0.001)$, whereas ER had the prescribed volume right more often (119 [66.1\%]; $\mathrm{p}=0.020)$ (Table 3) compared to the other groups.

There were $32 \mathrm{RBCs}$ with subtype (3.8\% of the total), 15 RBCs with only one subtype of red cells and 17 combining 2 or 3 subtypes. There was no difference between the sites of origin in relation to the subtype of red blood cells requested (Table 3).

\section{Discussion}

Our study identified that, among red blood cell transfusions performed, 1 in 3 and $41 \%$ were not in accordance with the current recommendations for indication and volume calculation, respectively. It should be emphasized that in none of the cases the use of specific subtypes of $\mathrm{RBC}$ would be indicated.

\begin{tabular}{|c|c|c|c|}
\hline \multicolumn{2}{|l|}{ Variable } & \multirow{2}{*}{$\begin{array}{l}\text { N } \\
\text { (adequate) } \\
240\end{array}$} & \multirow{2}{*}{$\begin{array}{l}\% \\
\text { (adequate) } \\
83.6\end{array}$} \\
\hline \multirow{6}{*}{$\begin{array}{l}\text { Clinical context } \\
(n=663)\end{array}$} & Septic shock & & \\
\hline & $\begin{array}{l}\text { Acute respiratory } \\
\text { failure }\end{array}$ & 115 & 92.7 \\
\hline & Pneumonia & 14 & 12 \\
\hline & $\begin{array}{l}\text { Hemodynamic } \\
\text { decompensation }\end{array}$ & 52 & 94.5 \\
\hline & $\begin{array}{l}\text { Mechanical } \\
\text { ventilation }\end{array}$ & 28 & 87.5 \\
\hline & Other & 21 & 43.7 \\
\hline Trigger $(n=814)$ & Adequate & 532 & 65.3 \\
\hline \multirow[t]{2}{*}{ Reason $(n=814)$} & $\begin{array}{l}\text { Clinical picture } \\
\text { was considered }\end{array}$ & 470 & 70.9 \\
\hline & $\mathrm{Hb}$ only & 62 & 41 \\
\hline \multirow{3}{*}{$\begin{array}{l}\text { Pre-transfusion } \mathrm{Hb} \\
(\mathrm{n}=814)\end{array}$} & $<7 \mathrm{~g} / \mathrm{dL}$ & 125 & 100 \\
\hline & 7 to $10 \mathrm{~g} / \mathrm{dL}$ & 391 & 67.2 \\
\hline & $>10 \mathrm{~g} / \mathrm{dL}$ & 16 & 15 \\
\hline $\begin{array}{l}\text { Volume adequacy } \\
(\mathrm{n}=782)\end{array}$ & Adequate & 460 & 58.8 \\
\hline \multirow[t]{5}{*}{ Subtype $(\mathrm{n}=837)$} & Plain RBC & 805 & 100 \\
\hline & $\begin{array}{l}\text { RBC with } \\
\text { subtype(s) }\end{array}$ & 0 & 0 \\
\hline & Filtered & 0 & 0 \\
\hline & Irradiated & 0 & 0 \\
\hline & Washed & 0 & 0 \\
\hline
\end{tabular}

Hb: hemoglobin; RBC: red blood cells.

\begin{tabular}{|c|c|c|c|c|}
\hline & ER & Infirmary & pICU & p-value \\
\hline \multirow[t]{2}{*}{ Adequate trigger } & $121 / 188$ & $68 / 147$ & $343 / 479$ & \multirow[t]{2}{*}{$<0.001$} \\
\hline & $(64.4 \%)$ & $(46.3 \%)$ & $(71.6 \%)^{*}$ & \\
\hline \multirow[t]{2}{*}{ Adequate volume } & $119 / 180$ & $66 / 131$ & $275 / 471$ & \multirow[t]{2}{*}{0.020} \\
\hline & $(66.1 \%)^{*}$ & $(50.4 \%)$ & $(58.4 \%)$ & \\
\hline \multirow[t]{2}{*}{ Adequate subtype } & $191 / 201$ & $140 / 148$ & $474 / 488$ & \multirow[t]{2}{*}{0.230} \\
\hline & (95.0\%) & (94.6\%) & (97.1\%) & \\
\hline
\end{tabular}

* Chi-square test significance level.

ER: emergency room; pICU: pediatric intensive care unit.

There was no difference between the male and female gender regarding the adequacy of the trigger, volume and subtype of the red blood cell concentrate. More than half of the transfusions occurred in children less than 1 year of age, data similar to those observed in a publication that included a similar population. ${ }^{28}$

In the trigger analysis, there was inadequacy mainly in transfusions based only on $\mathrm{Hb}$ values, without considering the clinical picture, with pre transfusion $\mathrm{Hb} \geq 10 \mathrm{~g} / \mathrm{dL}$, performed in the infirmary ward and in patients with respiratory disease without respiratory failure or mechanical ventilation. The largest study ever published with a pediatric population has shown that the prescription of red blood cells based on current recommendations decreases the number of transfused RBCs by $44 \% .{ }^{7}$ However, the study included exclusively children hospitalized in the PICU and thus in a clinical scenario different from ours with more stable children.

With respect to the prescribed volume, attention was drawn to the request for volumes above the recommended level, which increases the risk of transfusion-related circulatory overload. This transfusion reaction is one of the most frequent, with a growing incidence in the past years and mortality of $12 \%{ }^{20}$

The prescription of a specific subtype of RBCs leads to a longer waiting time for $\mathrm{RBC}$ concentrates, which may influence the prognosis of an unstable patient. After analyzing the requisitions, no clear justification for prescribing these components was found.

The ER did not document the value of $\mathrm{Hb}$ in $6.5 \%$ of the transfusion requests, a fact that can be partly explained by the greater instability of the patients. The infirmary ward failed to record the weight in 1 out of 10 request forms. This fact may increase the risk of inadequacy of the prescribed volume. Failure to record the weight and/or type of $\mathrm{Hb}$ makes it impossible for the transfusion agency to detect if there is any indication or calculation error and thus act to improve the transfusion practice of the service. 
Some hypotheses may be considered to justify the results obtained in our study. First, non-frequent updating of non-hematologic health professionals about proposed transfusion guidelines; second, the limited time available to address this issue in the medical undergraduate course and pediatric residency; and finally, the shortage of institutional continuing education programs on transfusion of blood components for the pediatric population.

Standardization of transfusion procedures according to current literature can reduce the cost of hospitalization, avoid waste of blood components and, especially, reduce the number of transfusion reactions. ${ }^{29}$

The implementation of continuing education in transfusion medicine should be emphasized at all levels (undergraduate, medical residency and professional) minimizing potential harm to the pediatric patient and the health care system. Emphasis should be given to the teaching of transfusion medicine in medical school and medical residency settings by both professor and preceptor, in addition to the updating of professionals by facilitating the provision of continuing education materials and courses, which could be done by hospital transfusion committees.

The results were reported to the hospital transfusion committee. Informative and up-to-date material on transfusional adequacy was prepared and is intended to be delivered to the pediatricians of the service, also available on the hospital's computers for consultation. Training for pediatricians who make RBC prescriptions at our institution was also proposed.

The strengths of this study include the number of transfusions analyzed, the analysis of requests made by pediatricians alone, a small percentage of loss $(6.5 \%)$ and the availability of an official guide that has been continually updated to compare the results obtained.

Regarding the limitations, the retrospective design, a lack of more detailed data on the clinical characteristics of the patients and the absence of a control between prescribed vs. infused volume can be cited.

\section{Conclusion}

The results obtained in our study show that transfusion of RBC concentrates was more adequate when clinical status was taken into account. Also, there was a tendency to prescribe high volumes and subtypes of erythrocytes that cannot be justified according to current protocols.

Improving teaching of hemotherapy at medical undergraduate and residency levels as well as the implementation of a continuing education project for pediatricians who work with critically ill children are crucial.

\section{Conflict of interest}

The authors declare no conflict of interest.

\section{Resumo}

Avaliação da prescrição de concentrados de hemácias na faixa etária pediátrica

Objetivo: Verificar a adequação na prescrição de concentrado de hemácias $(\mathrm{CH})$ por pediatras em diferentes setores de um hospital pediátrico.

Método: Realizou-se estudo retrospectivo onde avaliamos 837/990 fichas de requisição de $\mathrm{CH}$ para crianças e adolescentes ( 0 a 13 anos), preenchidas entre janeiro de 2007 e abril de 2015 pelos médicos pediatras do pronto-socorro (PS), da enfermaria e da unidade de terapia intensiva (UTI). Excluíram-se as transfusões realizadas em portadores de anemia crônica, crianças com hemorragia aguda e requisições incompletas.

Resultados: Gatilho, volume prescrito e subtipo de concentrado de hemácias foram adequados em 532 (65,3\%), $460(58,8 \%)$ e 805 (96,2\%) das transfusões, respectivamente. Quando foi considerado o quadro clínico, a adequação foi maior em comparação à prescrição pelo valor isolado da hemoglobina (70,9\% vs. $41 \%)$. A UTI teve o maior percentual de acerto no gatilho (343 [71,6\%]; $\mathrm{p}<0,001)$ e o PS, no volume prescrito (119 [66,1\%]; $\mathrm{p}=0,020)$. A inadequação mais comum, em relação ao volume, foi a prescrição acima da recomendação (> $15 \mathrm{~mL} / \mathrm{kg}, 309$ [36,9\%]). Foram solicitados 32 subtipos de $\mathrm{CH}$ e nenhum estava de acordo com as indicações atuais.

Conclusão: Os resultados obtidos mostram que a transfusão de $\mathrm{CH}$ aconteceu de forma mais adequada quando a situação clínica era levada em conta na solicitação. Houve uma tendência à prescrição de volumes elevados e de subtipos de hemácias não justificados segundo os protocolos atuais. É necessário melhorar o ensino de hemoterapia na graduação e residência médica.

Palavras-chave: Medicina Transfusional. Transfusão de Eritrócitos. Criança. Prescrições.

\section{References}

1. Hart S, Cserti-Gazdewich CM, McCluskey SA. Red cell transfusion and the immune system. Anaesthesia. 2015; 70(Suppl 1):38-45.

2. Parker RI. Transfusion in critically ill children: indications, risks and challenges. Crit Care Med. 2014; 42(3):675-90.

3. Salpeter SR, Buckley JS, Chatterjee S. Impact of more restrictive blood transfusion strategies on clinical outcomes: a meta-analysis and systematic review. Am J Med. 2014; 127(2):124-31.

4. Roubinian N, Carson JL. Red blood cell transfusion in adult and pediatric patients with malignancy. Hematol Oncol Clin North Am. 2016; 30(3):529-40. 
5. Shah A, Stanworth SJ, McKechnie S. Evidence and triggers for the transfusion of blood and blood products. Anaesthesia. 2015; 70(Suppl 1):10-9.

6. Carson JL, Grossman BJ, Kleinman S, Tinmouth AT, Marques MB, Fung MK, et al.; Clinical Transfusion Medicine Committee of the AABB. Red blood cell transfusion: a clinical practice guideline from the AABB. Ann Intern Med. 2012; 157(1):49-58.

7. Lacroix J, Hébert PC, Hutchison JS, Hume HA, Tucci M, Ducruet T, et al.; TRIPICU Investigators; Canadian Critical Care Trials Group; Pediatric Acute Lung Injury and Sepsis Investigators Network. Transfusion strategies for patients in pediatric intensive care units. N Engl J Med. 2007; 356(16):1609-19.

8. Hébert PC, Wells G, Blajchman MA, Marshall J, Martin C, Pagliarello G, et al. A multicenter, randomized, controlled clinical trial of transfusion requirements in critical care. Transfusion Requirements in Critical Care Investigators, Canadian Critical Care Trials Group. N Engl J Med. 1999; 340(6):409-17.

9. Villanueva C, Colomo A, Bosch A, Concepción M, Hernandez-Gea V, Aracil $\mathrm{C}$, et al. Transfusion strategies for acute upper gastrointestinal bleeding. $\mathrm{N}$ Engl J Med. 2013; 368(1):11-21.

10. Karam O, Tucci M, Ducruet T, Hume HA, Lacroix J, Gauvin F; Canadian Critical Care Trials Group; PALISI Network. Red blood cell transfusion thresholds in pediatric patients with sepsis. Pediatr Crit Care Med. 2011; 12(5):512-8.

11. Rouette J, Trottier H, Ducruet T, Beaunoyer M, Lacroix J, Tucci M; Canadian Critical Care Trials Group; PALISI Network. Red blood cell transfusion threshold in postsurgical pediatric intensive care patients: a randomized clinical trial. Ann Surg. 2010; 251(3):421-7.

12. Gibson BE, Todd A, Roberts I, Pamphilon D, Rodeck C, Bolton-Maggs P, et al.; British Commitee for Standards in Haematology Transfusion Task Force: Writing group. Transfusion guidelines for neonates and older children. Brit J Haematol. 2004; 124(4):433-53.

13. Society of Thoracic Surgeons Blood Conservation Guideline Task Force, Ferraris VA, Ferraris SP, Saha SP, Hessel EA 2nd, Haan CK, Royston BD, et al.; Society of Cardiovascular Anesthesiologists Special Task Force on Blood Transfusion. Perioperative blood transfusion and blood conservation in cardiac surgery: the Society of Thoracic Surgeons and The Society of Cardiovascular Anesthesiologists clinical practice guideline. Ann Thorac Surg. 2007; 83(5 Suppl):S27-86.

14. Carson JL, Terrin ML, Noveck H, Sanders DW, Chaitman BR, Rhoads GG, et al; FOCUS Investigators. Liberal or restrictive transfusion in high-risk patients after hip surgery. N Engl J Med. 2011; 365(26):2453-62.

15. Parker MM, Hazelzet JA, Carcillo JA. Pediatric considerations. Crit Care Med. 2004; 32(11 Suppl):S591-4.
16. Rivers E, Nguyen B, Havstad S, Ressler J, Muzzin A, Knoblich B, et al. Early goal-directed therapy in the treatment of severe sepsis and septic shock. N Engl J Med. 2001; 345(19):1368-77.

17. Stey AM, Vinocur CD, Moss RL, Hall BL, Cohen ME, Kraemer K, et al. Variation in intraoperative and postoperative red blood cell transfusion in pediatric surgery. Transfusion. 2016; 56(3):666-72.

18. Carson JL, Carless PA, Hébert PC. Outcomes using lower vs higher hemoglobin thresholds for red blood cell transfusion. JAMA. 2013; 309(1):83-4.

19. Rajasekaran S, Kort E, Hackbarth R, Davis AT, Sanfilippo D, Fitzgerald R, et al. Red cell transfusion as an independent risk for mortality in critically ill children. J Intensive Care Med. 2016; 4:2.

20. Lavoie J. Blood transfusion risks and alternative strategies in pediatric patients. Paediatr Anaesth. 2011; 21(1):14-24.

21. Schinagi CM, Mormanova ZH, Puchwein-Schwepcke A, Schimd I, GenzelBoroviczény $\mathrm{O}$. The effect of red blood cell transfusion on the microcirculation of anemic children. Eur J Pediatr. 2016; 175(6):793-8.

22. Castillo JJ, Dalia S, Pascual SK. Association between red blood cell transfusions and development of non-Hodgkin lymphoma: a meta-analysis of observational studies. Blood. 2010; 116(16):2897-907.

23. Slonim AD, Joseph JG, Turene WM, Sharangpani A, Luban NL. Blood transfusion in children: a multi-institutional analysis of practices and complications. Transfusion. 2008; 48(1):73-80.

24. Pedrosa AK, Pinto FJ, Lins LD, Deus GM. Blood transfusion reactions in children: associated factors. J Pediatr (Rio J). 2013; 89(4):400-6.

25. Brasil. Ministério da Saúde. Guia para o uso de hemocomponentes. Brasília: Ministério da Saúde; 2015 [cited 2016 Nov 14]. Available from: http://bvsms.saude.gov.br/bvs/publicacoes/guia_uso_hemocomponentes_ 2ed.pdf.

26. American College of Surgeons. Advanced trauma life support. 9. ed. Chicago: American College of Surgeons; 2012.

27. Chameides L, Samson RA, Schexnayder SM, Hazinski MF, Ashcraft J, Berg $\mathrm{MD}$, et al. Suporte avançado de vida em pediatria. São Paulo: American Heart Association; 2012.

28. Marvulo NL, Bonatto RC, Carpi MF, Ricchetti SM, Moraes MA, Fioretto JR. [Red blood cell transfusion in children admitted in a pediatric intensive care unit]. Rev Bras Ter Intensiva. 2006; 18(4):390-5.

29. Hasler S, Kleeman A, Abrams R, Kim J, Gupta M, Krause MK, et al. Patient safety intervention to reduce unnecessary red blood cell utilization. Am J Manag Care. 2016; 22(4):295-300. 